\title{
Historic diet change of the South American sea lion in Patagonia as revealed by isotopic analysis
}

\author{
M. Drago ${ }^{1, *}$, E. A. Crespo $^{2}$, A. Aguilar ${ }^{1}$, L. Cardona ${ }^{1}$, N. García ${ }^{2}$, S. L. Dans ${ }^{2}$, \\ N. Goodall ${ }^{3,4}$ \\ ${ }^{1}$ Department of Animal Biology, University of Barcelona, Av. Diagonal 645, 08028 Barcelona, Spain \\ ${ }^{2}$ Laboratory of Marine Mammals, Centro Nacional Patagonico (CENPAT-CONICET), and National University of Patagonia, \\ Blvd. Brown 3600, 9120 Puerto Madryn, Argentina \\ ${ }^{3}$ Acatushún Museum, 9410 Ushuaia, Tierra del Fuego, Argentina \\ ${ }^{4}$ Centro Austral de Investigaciones Científicas (CADIC), Bernardo A. Houssay 200, V9410CAB Ushuaia, \\ Tierra del Fuego, Argentina
}

\begin{abstract}
Carbon and nitrogen isotopic analyses of skull bone were used to investigate how sealing and the development of industrial fishing have affected the diet of the South American sea lion Otaria flavescens in northern Patagonia. Males from Tierra del Fuego were used as a control, as the species there was decimated by sealing, but industrial fishing is only poorly developed. The $\delta^{13} \mathrm{C}$ of both males and females from northern Patagonia increased from the 1940s to the 1970s, and then declined steadily. The decline in the slope was similar in both sexes, although females were more depleted in ${ }^{13} \mathrm{C}$ than were males. The $\delta^{15} \mathrm{~N}$ remained unaffected in males throughout the period, whereas that of females decreased from the 1940s to the 1970s and then stabilized. Conversely, no change was found in either the $\delta^{13} \mathrm{C}$ or $\delta^{15} \mathrm{~N}$ in the skulls from Tierra del Fuego animals. As benthic prey off northern Patagonia are more enriched in ${ }^{13} \mathrm{C}$ than are pelagic prey, the above results indicate increased consumption of benthic coastal prey in this region from the 1940s to the 1970s, when sea lions were decimated by commercial hunting, and increased consumption of pelagic prey since the 1970s, simultaneous with sea lion population recovery. Reinforced intraspecific competition and massive discard of pelagic fish likely contributed to the observed dietary shift, while the poorly developed industrial fishing off Tierra del Fuego did not facilitate a similar change there. Nevertheless, physical forcing related to regime changes observed in the Pacific Ocean since the 1970s may also have played a role.
\end{abstract}

KEY WORDS: South American sea lion · Otaria flavescens · Dietary shift · Stable isotopes · Bone Fishery interactions · Discarded fish

Resale or republication not permitted without written consent of the publisher

\section{INTRODUCTION}

Exploitation of marine ecosystems is causing a rapid depletion of top predators worldwide (Pauly et al. 1998, Jackson \& Sala 2001, Myers \& Worm 2003). As a result, marine food webs are undergoing such extraordinary changes in their structure and function (Springer et al. 2003, Emslie \& Patterson 2007) that, if the system has reached a new stable state, these may prevent the restoration of the original dynamics of the ecosystem once human exploitation ceases (Petraitis \& Dudgeon 2004).
Many otariid species were led to the brink of extinction during the 19th and 20th centuries, due to commercial exploitation for their pelts and fat (Bonner 1982). After killing ceased, some species quickly recovered, but others failed to do so, often because they had been out-competed by commercial fishing (Trites 1992, National Research Council 2002, Costa et al. 2006). Typically, the species that failed to recover were benthic foragers, as they often operate near their physiological dive capability and, for this reason, have a lower capacity to increase their foraging effort in response to the re- 
duction in food availability caused by fishing (Costa et al. 2004). Fishing may not only reduce the total abundance of prey, but may also modify the structure of the ecosystem and reduce the nutritional quality of the remaining prey (Trites \& Donnelly 2003). Conversely, pelagic foragers tend to recover quickly, perhaps because they benefit by the new ecosystem structure induced by human exploitation other than sealing (Hodgson \& Johnston 1997, Costa et al. 2004, 2006).

In the south-western Atlantic, the South American sea lion Otaria flavescens was heavily exploited from the 1920s to the 1960s (Godoy 1963). Most populations had been reduced to $<10 \%$ of their original number when exploitation ceased, and population recovery did not begin in Argentina until the early 1990s, after several decades of stagnation (Crespo \& Pedraza 1991, Reyes et al. 1999, Schiavini et al. 2004).The population from the Falkland (Malvinas) Islands, however, has not yet recovered (Thompson et al. 2005).

The drastic reduction in the South American sea lion was not the only human impact on the ecosystem off northern Patagonia, as a high-sea fishery targeting Argentine hake Merluccius hubbsi was established there in the 1970s (Crespo et al. 1997, Bertolotti et al. 2001). The development of fishing dramatically reduced the hake population (Lloris et al. 2003, Koen Alonso \& Yodzis 2005), which, combined with the extreme reduction in the sea lion population, led to a severe reorganization of the whole ecosystem (Koen Alonso \& Yodzis 2005). Among the consequences of such changes were the increase of the Magellanic penguin Spheniscus magellanicus population (Carribero et al. 1995) and several shifts in the diet of some former hake predators, like the spiny dogfish Squalus acanthias (Koen Alonso et al. 2002).

At first glance, these changes have not hindered the recovery of the southern sea lion population in northern Patagonia, which increased at about $6 \%$ annually from 1983 to 2002 (Dans et al. 2004). Currently, hake is a primary prey for the South American sea lion in northern Patagonia (Koen Alonso et al. 2000), and culling has been considered as a possible management strategy for sea lions in order to rebuild the hake stocks (Koen Alonso \& Yodzis 2005). However, it is unknown whether South American sea lions reduced their per capita consumption of Argentine hake and increased that of other species as the hake stock declined and the population of sea lions increased, or whether they maintained a strong preference for hake, as assumed by Koen Alonso \& Yodzis (2005). This issue is relevant not only to better understand the role of sea lions in the dynamics of the ecosystem, but also to determine whether alternative prey may differ in nutritional quality, a factor which could potentially influence the recovery of South American sea lions.
Inferring changes in the position of South American sea lions in the food web throughout the 20th century is one possible way to answer these questions. In the present paper, we have attempted to provide such information through retrospective analysis of stable isotopes in the skull bone of individuals stranded over the past 7 decades. The analysis of stable isotopes is a powerful means to infer food-web position changes, because the isotopic content in the tissues of a consumer reflects that of their overall prey in a predictable manner over a period of time (DeNiro \& Epstein 1978, DeNiro \& Epstein 1981). The extent of the time period over which this method reveals useful information depends on the biochemical turnover rate of the analysed tissue, because turnover rates of stable isotopes in tissues vary according to tissue metabolic rate. As a consequence, tissues with high turnover rates provide dietary information assimilated from recent feeding bouts, while tissues with lower turnover rates provide dietary information assimilated from more remote feeding bouts (Tieszen et al. 1983, Hobson \& Clark 1992, Hobson 1993). Bone tissue acts as a longterm integrator of isotope ratios and moderator of sporadic isotopic fluctuations, due to its relatively slow turnover, which makes it useful for comparing the isotope ratios of many individuals over long periods of time (Schoeninger \& DeNiro 1984, Lee-Thorp et al. 1989, Hirons et al. 2001).

The specific aims of the present study were: (1) to determine whether the diet of South American sea lions in northern Patagonia changed as industrial fishing and sea lion exploitation modified the structure of the whole ecosystem throughout the 20th century and (2) to assess whether any changes that occurred modified the nutritional quality of the diet.

\section{MATERIALS AND METHODS}

Sampling. Fig. 1 shows the distribution of the South American sea lion Otaria flavescens along the coastline of Argentina and the Falkland (Malvinas) Islands and the fishing grounds exploited by the Argentine industrial fishing fleet. Skulls sampled to determine changes in the isotopic values of bone tissue came from 3 sources: (1) the collections from the Centro Nacional Patagonico (CENPAT) at Puerto Madryn, which contained skulls of individuals stranded from 1974 to 2002 along the coast of the heavily fished area off Chubut Province, in northern Patagonia ( $\mathrm{n}=30$ males and $\mathrm{n}=$ 30 females); (2) the collection from the Acatushún Museum at Ushuaia, which contained skulls of individuals stranded from 1970 to 2007 along the coast of Tierra del Fuego, an area located about $1500 \mathrm{~km}$ south on the same coastline and that has been subject to 


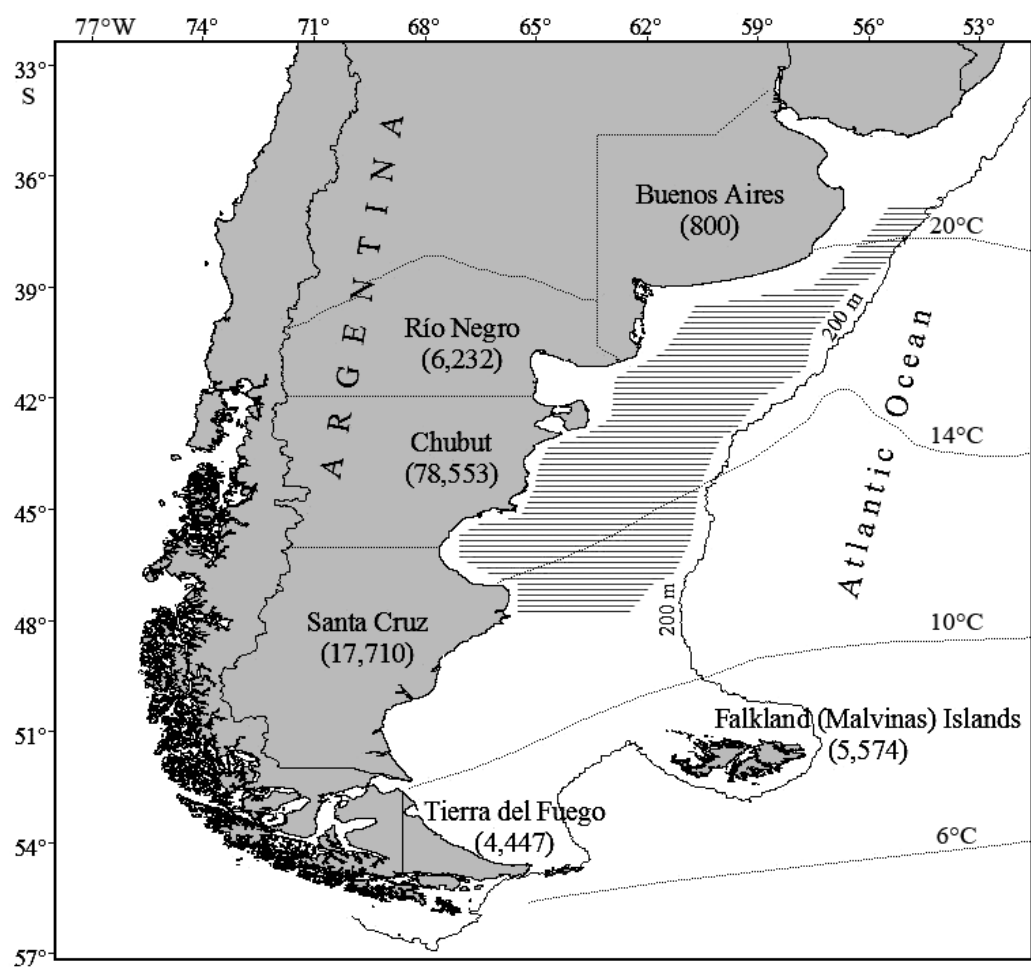

Fig. 1. Otaria flavescens. Distribution of the South American sea lions along the coastline of Argentina and the Falkland (Malvinas) Islands in the mid1990s. Parentheses: population size for each province/area in agreement with Reyes et al. (1999), Dans et al. (2004), Schiavini et al. (2004), Thompson et al. (2005), Grandi et al. (2008), and G. Giardino (pers. comm.). Isotherms: sea surface temperature during summer (Hoffmann et al. 1997). Hatching: fishing grounds exploited by the Argentine industrial fishing fleet in the second half of the 1980s and in the 1990s (Giangiobbe et al. 1993, Dato et al. 2003a)

spanned 2 of the 3 periods considered were assigned to the most recent of the periods.

The 3 periods were established in agreement with the evolution of the sea lion (Dans et al. 2003, Koen Alonso \& Yodzis 2005) and hake populations (Lloris et al. 2003, Koen Alonso \& Yodzis 2005) as shown in Fig. 2a,b. The first period (1965 to 1980) was characterized by high hake availability, as both the fishery landings and the population of South American sea lions were small. The second period (1981 to 1997) was characterized by declining food availability, as indicated by very large hake landings. The third period (1998 to 2002) was characterized by a population of South American sea lions in the process of recovery as well as by the collapse of the hake fishery.

The skull sample used for the isotopic analysis consisted of a small fragment of turbinate bones from the nasal cavity to avoid damaging the skull for subsequent studies (CENPAT and Acatushún Museum) or from the tympanic bulla when the turbinated bones were not in good condition (hunting site). The samples were stored dry until analysis.

Koen Alonso et al. (2000) have identified the Argentine anchovy Engraulis

much lower fishing pressure (Bertolotti et al. 2001) ( $\mathrm{n}=$ 21 males); and (3) skulls collected for the study from a hunting site at Península Valdés (Chubut Province), which contained skeletal remains from the commercial exploitation in the 1940s, a period when the population of South American sea lions was about $60 \%$ of its original size and hake was not yet subject to industrial fishing (Fig. 2a,b) ( $\mathrm{n}=10$ males and 5 females) (Bertolotti et al. 2001, Dans et al. 2003, Koen Alonso \& Yodzis 2005).

All the skulls included in the present study were considered to belong to physically mature sea lions, although the age of the individuals whose skulls were sampled at the Península Valdés hunting site and the Acatushún Museum is unknown (Table 1). The individuals from the CENPAT collection had previously been aged by counting growth layer groups in the dentine of the canines (Crespo 1988, Crespo et al. 1994) and were selected according to the following criteria: a similar age (male range: 7 to $14 \mathrm{yr}_{\text {; }}$ female range: 6 to $15 \mathrm{yr}$ ) and adult lifetime spanning only 1 of the 3 different periods in which food availability was considered to be dissimilar. Those individuals whose adult lifetime anchoita, the red octopus Enteroctopus megalocyathus, the Argentine short-fin squid Illex argentinus, the Patagonian squid Loligo gahi, the South American long-fin squid Loligo sanpaulensis, the Argentine hake Merluccius hubbsi, the tehuelche octopus Octopus tehuelchus, the flounder Paralichthys isosceles, and the banded cusk eel Raneya brasiliensis as potential prey for South American sea lions off Chubut Province. Individuals from all these species were sampled to determine their energy density and isotopic signal. Samples of benthic primary producers (Codium vermilara and Undaria pinnatifida) and phytoplankton (diatoms and dinoflagellates) were also collected to determine their isotopic signal and, hence, to produce a complete picture of the isotopic landscape off Chubut Province. These samples were provided by local fishermen or collected on board by staff from the CENPAT. The phytoplankton was collected with a plankton net (20 $\mu \mathrm{m}$ mesh size) and, once in the laboratory, filtered with a precombusted GF/C filter. All samples were stored in a freezer at $-20^{\circ} \mathrm{C}$.

Stable isotope analysis. In the laboratory, samples were thawed, when needed, dried in a stove at $60^{\circ} \mathrm{C}$ 

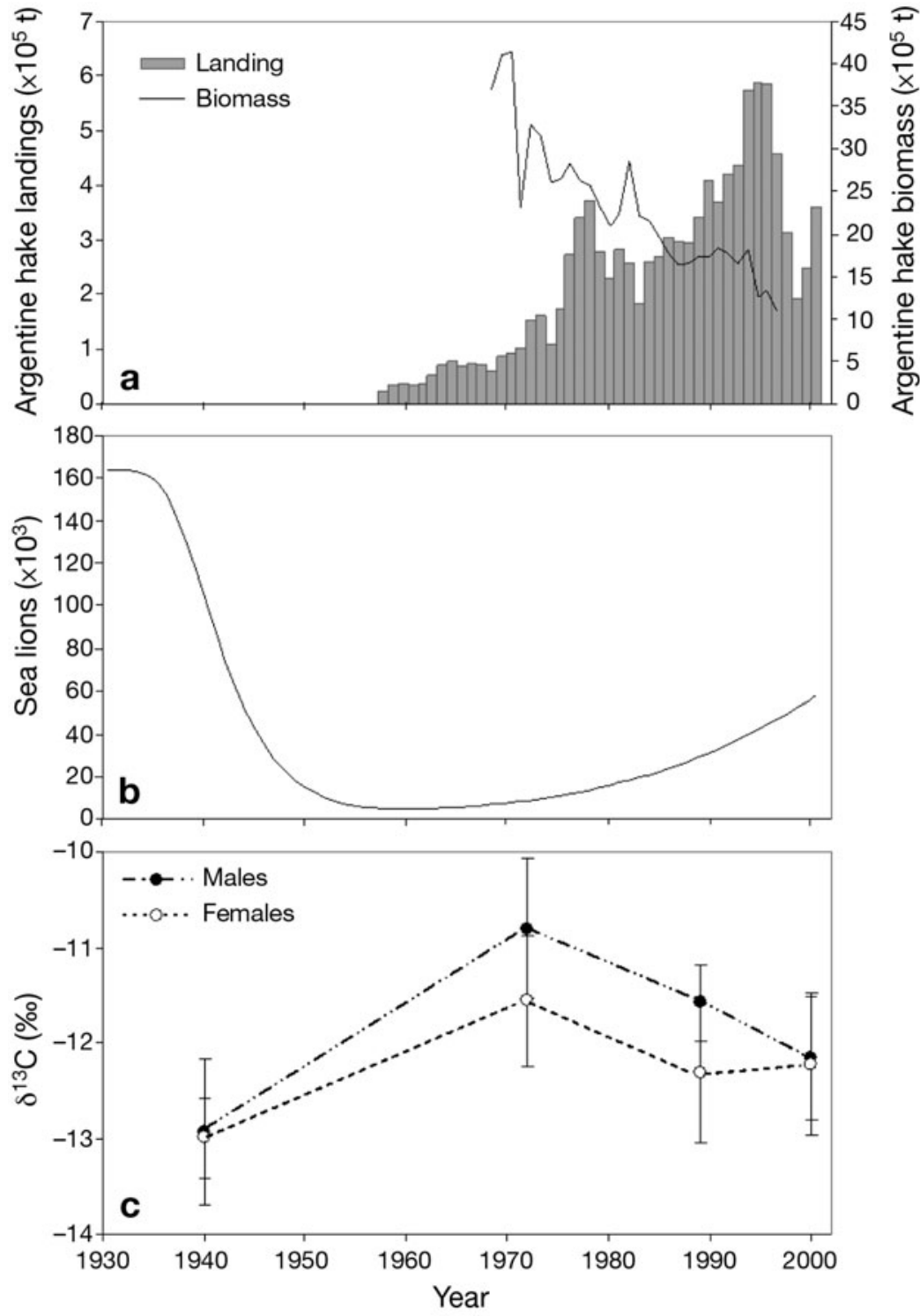

Fig. 2. (a) Hake Merluccius hubbsi landings (from Dans et al. 2003) and hake biomass (from Koen Alonso \& Yodzis 2005), (b) trajectory of the sea lion Otaria flavescens population in northern and central Patagonia (from Koen Alonso \& Yodzis 2005), (c) trajectory of the average $\delta^{13} \mathrm{C}$ in the skull bone of sea lions from Chubut Province (Península Valdés hunting site and CENPAT collection) in 4 contrasting periods (present study). The year associated with each $\delta^{13} \mathrm{C}$ value is the median of each sampling period. Error bars: SD

for $36 \mathrm{~h}$, and ground to a fine powder with a mortar and pestle. Lipids were extracted with a chloroform/ methanol (2:1) solution (Bligh \& Dyer 1959), because they are depleted in ${ }^{13} \mathrm{C}$ compared with other molecules and may therefore artefactually decrease the overall tissue $\delta^{13} \mathrm{C}$ signal (DeNiro \& Epstein 1977, Tieszen et al. 1983). As bone and phytoplankton samples contain high concentrations of inorganic carbon, which may cause undesirable variability to $\delta^{13} \mathrm{C}$ (Lorrain et al. 2003), they were previously treated by soak- ing for $24 \mathrm{~h}$ in $0.5 \mathrm{~N}$ (bone) and $0.05 \mathrm{~N}$ (phytoplankton) hydrochloric acid $(\mathrm{HCl})$ to decarbonise them (Ogawa \& Ogura 1997, Newsome et al. 2006). Since $\mathrm{HCl}$ treatment adversely affects $\delta^{15} \mathrm{~N}$ (Bunn et al. 1995), each of the samples was divided into 2 subsamples: one was used for $\mathrm{C}$ analyses after decarbonation and the other was used for $\mathrm{N}$ analyses without decarbonation.

Approximately $1 \mathrm{mg}$ of dried bone, $4.0 \mathrm{mg}$ of homogenised seaweeds, $16.0 \mathrm{mg}$ of homogenised phytoplankton with filter, and $0.6 \mathrm{mg}$ of white muscle from fish and of mantle from cephalopods were weighed into tin cups $(3.3 \times$ $5 \mathrm{~mm}$ ), combusted at $900^{\circ} \mathrm{C}$, and analysed in a continuous flow isotope ratio mass spectrometer (Flash 1112 IRMS Delta C Series EA Thermo Finnigan). Atropine was used as a system check for elemental analyses.

Stable isotope abundances, expressed in delta $(\delta)$ notation, in which the relative variations of stable isotope ratios are expressed in per mille (\%o) deviations from predefined international standards, were calculated as:

$$
\delta X=\left[\left(R_{\text {sample }} / R_{\text {standard }}\right)-1\right] \times 10^{3}
$$

where $X$ is ${ }^{13} \mathrm{C}$ or ${ }^{15} \mathrm{~N}$, $R_{\text {sample }}$ is the heavy to light isotope ratio of the sample $\left({ }^{13} \mathrm{C} /{ }^{12} \mathrm{C}\right.$ or $\left.{ }^{15} \mathrm{~N} /{ }^{14} \mathrm{~N}\right)$, and $R_{\text {standard }}$ is the heavy to light isotope ratio of the reference standards, which were VPDB (Vienna Pee Dee Belemnite) calcium carbonate for ${ }^{13} \mathrm{C}$ and atmospheric nitrogen (air) for ${ }^{15} \mathrm{~N}$. International isotope secondary standards of known ${ }^{13} \mathrm{C} /{ }^{12} \mathrm{C}$ ratios, as given by the IAEA (International Atomic Energy Agency IAEA), namely polyethylene (IAEA $\mathrm{CH}_{7}, \delta^{13} \mathrm{C}=$ $-31.8 \%$ ), graphite (IAEA USGS ${ }_{24}, \delta^{13} \mathrm{C}=$ $-16.1 \%$ ) and sucrose (IAEA $\mathrm{CH}_{6}, \delta^{13} \mathrm{C}=$ $-10.4 \%)$, were used for calibration at a precision of $0.2 \%$. For nitrogen, international isotope secondary standards of known ${ }^{15} \mathrm{~N} /{ }^{14} \mathrm{~N}$ ratios, namely $\left(\mathrm{NH}_{4}\right)_{2} \mathrm{SO}_{4}\left(\right.$ IAEA N $1, \delta^{15} \mathrm{~N}=+0.4 \%$ and IAEA $\mathrm{N}_{2}, \delta^{15} \mathrm{~N}=$ $+20.3 \%)$ and $\mathrm{KNO}_{3}\left(\right.$ IAEA $\mathrm{NO}_{3}, \delta^{15} \mathrm{~N}=+4.7 \%$ ), were used to a precision of $0.3 \%$.

Energy density. After thawing, samples were weighed and dried in a stove at $100^{\circ} \mathrm{C}$ until a constant weight was reached. The moisture content was calculated by the gravimetric difference between wet and dry mass (Eder \& Lewis 2005). The dry tissue was then 
Table 1. Otaria flavescens. Skulls of South American sea lions investigated in the present study. Only 1 sample from each skull was analysed. Adult: physically mature sea lions of unknown age; 1940s: individuals from a hunting site at Península Valdés (Chubut Province) that contained skeletal remains from commercial exploitation in the 1940s

\begin{tabular}{|c|c|c|c|c|c|c|c|c|c|c|c|}
\hline $\begin{array}{l}\text { Sample number } \\
\text { and location }\end{array}$ & Sex & $\begin{array}{l}\text { Age } \\
\text { (yr) }\end{array}$ & $\begin{array}{c}\text { Dead/ } \\
\text { stranding } \\
\text { year }\end{array}$ & $\begin{array}{l}\delta^{13} \mathrm{C} \\
(\% \circ)\end{array}$ & $\begin{array}{c}\delta^{15} \mathrm{~N} \\
(\% \circ)\end{array}$ & $\begin{array}{l}\text { Sample number } \\
\text { and location }\end{array}$ & Sex & $\begin{array}{l}\text { Age } \\
\text { (yr) }\end{array}$ & $\begin{array}{c}\text { Dead/ } \\
\text { stranding } \\
\text { year }\end{array}$ & $\begin{array}{l}\delta^{13} \mathrm{C} \\
(\% \circ)\end{array}$ & $\begin{array}{l}\delta^{15} \mathrm{~N} \\
(\%)\end{array}$ \\
\hline Chubut Province & & & & & & OF 127 & ㅇ & 6.5 & 1983 & -12.2 & 22.0 \\
\hline 1 & $0^{1}$ & Adult & $1940 \mathrm{~s}$ & -13.4 & 23.1 & OF 29 & o & 14 & 1980 & -10.6 & 22.0 \\
\hline 2 & $0^{1}$ & Adult & $1940 \mathrm{~s}$ & -12.1 & 22.2 & OF 61 & o & 10 & 1982 & -10.4 & 24.0 \\
\hline 3 & $0^{7}$ & Adult & $1940 \mathrm{~s}$ & -11.9 & 22.9 & OF 88 & 오 & 10 & 1982 & -11.5 & 21.5 \\
\hline 4 & $0^{7}$ & Adult & $1940 \mathrm{~s}$ & -13.3 & 23.9 & OF 85 & 오 & 12 & 1982 & -11.5 & 21.9 \\
\hline 5 & $0^{7}$ & Adult & $1940 \mathrm{~s}$ & -13.7 & 23.7 & OF 117 & 오 & 15 & 1982 & -11.2 & 21.8 \\
\hline 6 & $0^{7}$ & Adult & $1940 \mathrm{~s}$ & -14.0 & 21.8 & OF 128 & 우 & 9.5 & 1983 & -11.9 & 22.2 \\
\hline 7 & $0^{7}$ & Adult & $1940 \mathrm{~s}$ & -12.9 & 21.6 & OF 168 & 우 & 9 & 1984 & -11.5 & 21.8 \\
\hline 8 & $0^{1}$ & Adult & $1940 \mathrm{~s}$ & -11.9 & 23.9 & OF 215 & 우 & 8 & 1990 & -12.3 & 22.2 \\
\hline 9 & $0^{7}$ & Adult & $1940 \mathrm{~s}$ & -13.6 & 22.6 & OF 229 & 아 & 11 & 1990 & -11.9 & 21.8 \\
\hline 10 & $0^{7}$ & Adult & $1940 \mathrm{~s}$ & -12.6 & 24.0 & OF 225 & 아 & 12 & 1990 & -13.1 & 21.6 \\
\hline OF 21 & $0^{7}$ & 14 & 1974 & -11.6 & 21.4 & OF 234 & 우 & 13 & 1990 & -11.7 & 22.2 \\
\hline OF 22 & $0^{7}$ & 11 & 1977 & -10.9 & 24.7 & OF 236 & 우 & 7 & 1991 & -12.3 & 22.1 \\
\hline OF 30 & $0^{1}$ & 7 & 1979 & -10.5 & 23.6 & OF 243 & 우 & 7 & 1992 & -13.0 & 21.9 \\
\hline OF 32 & $0^{\prime \prime}$ & 7 & 1979 & -11.3 & 23.0 & OF 262 & ㅇ & 9 & 1993 & -12.0 & 23.3 \\
\hline OF 34 & $0^{7}$ & 11 & 1979 & -11.0 & 21.8 & OF 248 & ㅇ & 10 & 1993 & -13.6 & 21.6 \\
\hline OF 27 & $0^{7}$ & 7.3 & 1980 & -11.6 & 20.7 & OF 252 & ㅇ & 10 & 1993 & -11.6 & 22.8 \\
\hline OF 58 & $0^{x}$ & 8.5 & 1981 & -9.8 & 22.0 & OF 394 & q & 8.5 & 1994 & -12.1 & 22.2 \\
\hline OF 49 & $0^{x}$ & 8 & 1982 & -11.5 & 20.2 & OF 367 & q & 9.5 & 1994 & -12.0 & 22.6 \\
\hline OF 116 & $0^{x}$ & 10 & 1982 & -9.6 & 22.7 & OF 417 & q & 10 & 1995 & -11.8 & 22.4 \\
\hline OF 118 & $0^{1}$ & 10 & 1983 & -10.3 & 22.4 & OF 453 & 우 & 13 & 1996 & -11.5 & 23.4 \\
\hline OF 202 & $0^{1}$ & 9 & 1987 & -12.0 & 21.9 & OF 451 & 우 & 12.5 & 1996 & -11.6 & 22.0 \\
\hline OF 206 & $0^{7}$ & 12 & 1987 & -11.0 & 22.4 & OF 455 & 우 & 7.5 & 1996 & -13.3 & 21.7 \\
\hline OF 213 & $0^{7}$ & 12 & 1990 & -11.9 & 23.0 & OF 559 & 우 & 10 & 2000 & -12.6 & 22.0 \\
\hline OF 217 & $0^{7}$ & 11 & 1990 & -11.6 & 22.0 & OF 567 & 우 & 15 & 2000 & -11.1 & 23.2 \\
\hline OF 230 & $0^{1}$ & 9 & 1990 & -11.4 & 19.1 & OF 600 & 우 & 6.5 & 2002 & -13.1 & 21.0 \\
\hline OF 228 & $0^{1}$ & 12 & 1990 & -11.0 & 22.4 & OF 587 & 우 & 9.5 & 2002 & -13.0 & 22.4 \\
\hline OF 238 & $0^{1}$ & 7 & 1991 & -11.3 & 24.1 & Tierra del Fuego & & & & & \\
\hline OF 245 & $0^{7}$ & 7 & 1992 & -12.1 & 21.8 & S/N 2 & $0^{11}$ & Adult & 1970 & -12.3 & 23.4 \\
\hline OF 250 & $0^{7}$ & 9 & 1993 & -11.9 & 23.2 & 951 & $0^{4}$ & Adult & 1981 & -12.5 & 18.2 \\
\hline OF 254 & $0^{7}$ & 10 & 1993 & -11.6 & 23.4 & 917 & $0^{1}$ & Adult & 1981 & -13.2 & 18.5 \\
\hline OF 503 & $0^{x}$ & 8 & 1998 & -12.3 & 22.7 & 1525 & $0^{x}$ & Adult & 1985 & -11.6 & 22.4 \\
\hline OF 520 & $0^{x}$ & 12 & 1999 & -12.8 & 21.6 & 1180 & $0^{x}$ & Adult & 1985 & -12.9 & 19.7 \\
\hline OF 521 & $0^{7}$ & 9 & 1999 & -11.4 & 22.9 & 1748 & $0^{7}$ & Adult & 1994 & -14.9 & 22.2 \\
\hline OF 526 & $0^{7}$ & 10 & 2000 & -12.9 & 20.3 & 2319 & $0^{7}$ & Adult & 2003 & -12.7 & 20.2 \\
\hline OF 530 & $0^{7}$ & 9 & 2000 & -12.2 & 22.3 & 2371 & $0^{\pi}$ & Adult & 2005 & -12.5 & 21.3 \\
\hline OF 531 & $0^{7}$ & 10 & 2000 & -12.5 & 21.6 & 2396 & $0^{7}$ & Adult & 2006 & -13.4 & 20.9 \\
\hline OF 540 & $0^{7}$ & 11 & 2000 & -12.2 & 20.7 & 2395 & $0^{7}$ & Adult & 2006 & -13.8 & 21.0 \\
\hline OF 542 & $0^{7}$ & 7 & 2000 & -11.7 & 21.5 & 2468 & $0^{7}$ & Adult & 2007 & -12.9 & 21.3 \\
\hline OF 553 & $0^{1}$ & 10 & 2000 & -12.7 & 20.9 & 2467 & $0^{7}$ & Adult & 2007 & -13.7 & 20.6 \\
\hline OF 582 & $0^{1}$ & 10 & 2001 & -10.9 & 23.5 & 2464 & $0^{11}$ & Adult & 2007 & -12.9 & 20.5 \\
\hline 11 & ㅇ & Adult & $1940 \mathrm{~s}$ & -12.5 & 24.4 & 2463 & $0^{17}$ & Adult & 2007 & -13.2 & 20.6 \\
\hline 12 & ㅇ & Adult & $1940 \mathrm{~s}$ & -13.5 & 24.1 & 2458 & $0^{1}$ & Adult & 2007 & -13.6 & 20.5 \\
\hline 13 & ᄋ & Adult & $1940 \mathrm{~s}$ & -13.1 & 23.0 & 2457 & $0^{1}$ & Adult & 2007 & -12.0 & 20.9 \\
\hline 14 & ㅇ & Adult & $1940 \mathrm{~s}$ & -13.2 & 23.5 & 2469 & $0^{11}$ & Adult & 2007 & -13.5 & 20.7 \\
\hline 15 & ㅇ & Adult & $1940 \mathrm{~s}$ & -12.6 & 23.4 & 2461 & $0^{x}$ & Adult & 2007 & -13.0 & 21.2 \\
\hline OF 52 & ㅇ & 6 & 1980 & -11.9 & 21.7 & 2471 & $0^{x}$ & Adult & 2007 & -13.1 & 20.6 \\
\hline OF 33 & 운 & 6.1 & 1980 & -12.6 & 23.1 & 2456 & $0^{x}$ & Adult & 2007 & -12.4 & 21.2 \\
\hline OF 26 & ㅇ & 13 & 1980 & -12.0 & 21.6 & 2475 & $0^{7}$ & Adult & 2007 & -13.1 & 20.7 \\
\hline
\end{tabular}

homogenised, and a subsample was analysed in a mass spectrometer (Flash 1112 IRMS Delta C Series EA Thermo Finnigan) to determine its nitrogen content, a value that was later multiplied by a conversion factor of 5.8 to obtain the relative richness of protein in the dry material (Gnaiger \& Bitterlich 1984, Clarke et al. 1992). Another subsample was treated with a chloroform/ methanol (2:1) solution to determine its lipid content by the gravimetric difference between whole tissue and fat-free tissue dry mass (Bligh \& Dyer 1959).

Protein and lipid contents were converted to energy density using the mean combustion equivalents reported by Clarke et al. (1992), i.e. 23.9 and $39.5 \mathrm{~kJ} \mathrm{~g}^{-1}$, respectively. Carbohydrate content was not measured, 
because it is generally assumed to have a negligible contribution to the energetic value of fish (Sidwell et al. 1974, Craig et al. 1978).

Data analyses. Data are always shown as means \pm standard deviation (SD), unless otherwise stated. Prior to any statistical analyses, normality of the data was tested by means of the Lilliefors test, and homoscedasticity, by means of the Levene test.

The differences in the $\delta^{13} \mathrm{C}, \delta^{15} \mathrm{~N}$ and energy density of the prey species from the 2 considered habitats (benthic vs. pelagic) were tested by means of nested ANOVA.

The differences in the bone isotopic signal of males and females from the different sampling periods in Chubut Province (Península Valdés hunting site and CENPAT collection) were tested by 2-way ANOVA (Sex $\times$ Period). One-way ANOVA, followed by a Tukey (when the sample size was homogeneous among sampling periods) or Scheffé (when the sample size was not homogenous among sampling periods) post hoc test was carried out to compare the isotopic signal of individuals of the same sex in the 4 periods considered.

Time trends in the isotopic signal of the bones from the CENPAT and the Acatushún Museum collections were investigated by linear regression analysis, although the non-parametric Spearman's $\rho$ correlation coefficient was used when data did not fit the criteria for normality. The resulting equations were compared by means of coincidence and parallelism tests (Zar 1984): the first of these assesses the hypothesis that the 2 linear regression equations are coincidental because they do not differ either in their slope or elevation and the second test assesses the hypothesis that the 2 linear regression equations do not differ in their slope.

Because the sample sizes of skulls from the CENPAT and the Acatushún Museum were different (30 skulls from the CENPAT vs. 21 skulls from the Acatushún Museum) and the distributions of the years when individuals stranded were not identical, we performed a randomization analysis to investigate whether such differences might influence the sensibility of the regressions fitted to the data. Thus, 100 randomized populations with the same sample size and stranding year distribution as those from the Acatushún Museum were created from the CENPAT dataset and then a linear regression between the isotopic signal and the stranding year was computed for each randomized population. The possibility of detecting a significant correlation was not considered to be hindered by the structure of the datasets if $\geq 95 \%$ of the randomized populations exhibited a positive correlation between year of stranding and isotopic signal.

All statistical analyses were conducted with the SPSS 15 software package.

\section{RESULTS}

The $\delta^{13} \mathrm{C}$ of the primary producers ranged from -14.9 $\pm 1.3 \%$ for seaweeds to $-21 \pm 0.1 \%$ o for phytoplankton. That of the potential prey of South American sea lions Otaria flavescens ranged from $-14.6 \pm 0.7 \%$ for benthic species like the red octopus Enteroctopus megalocyathus to $-17.9 \pm 0.2 \%$ for pelagic prey like the Argentine anchovy Engraulis anchoita (Fig. 3, Table 2). Although adult hakes Merluccius hubbsi are often considered to be demersal pelagic, their $\delta^{13} \mathrm{C}$ is closer to that of pelagic species than to that of benthic species (Fig. 3, Table 2). This is because adult hakes spend daylight hours close to the sea bed, but move to the top layers of the water column at night to feed on pelagic species (Angelescu \& Fuster de Plaza 1965). For this reason, in latter analyses, adult hakes have been included as members of the pelagic assemblage.

When benthic and pelagic prey were compared, the nested ANOVA (Table 3) showed that benthic prey $\left(\delta^{13} \mathrm{C}:-15.1 \pm 0.6 \% ; \delta^{15} \mathrm{~N}: 18.9 \pm 0.8 \%\right.$ ) were more enriched both in ${ }^{13} \mathrm{C}$ and ${ }^{15} \mathrm{~N}$ than the pelagic prey $\left(\delta^{13} \mathrm{C}:-17.3 \pm 0.5 \%\right.$; $\delta^{15} \mathrm{~N}: 15.9 \pm 1.3 \%$ ). The nested ANOVA also indicated that benthic prey had a lower average energy density than did pelagic prey,

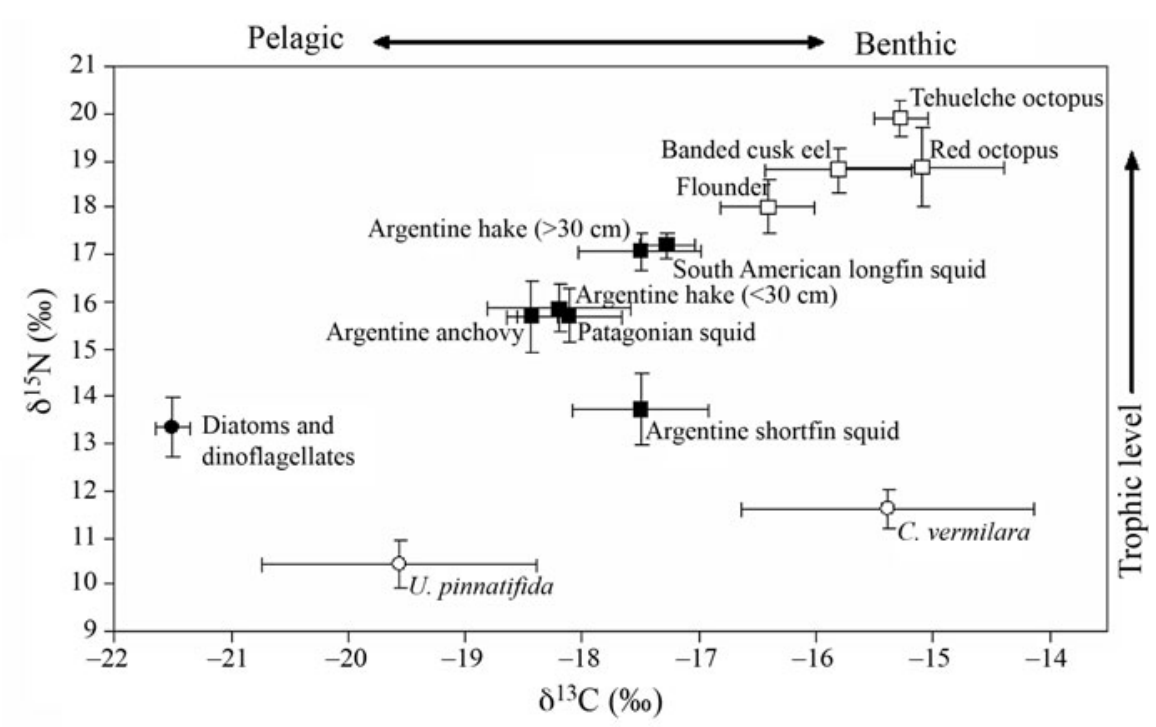

Fig. 3. Bivariated isotopic signal of the primary producers and main prey of the South American sea lion Otaria flavescens off Chubut Province. Primary producers: seaweeds Codium vermilara and Undaria pinnatifida (O), phytoplankton $(\bullet)$. Main prey: benthic (口), pelagic $(\square)$. Error bars: SD 
Table 2. Otaria flavescens. Mean $( \pm \mathrm{SD})$ isotopic signals of primary producers and of the potential prey of the South American sea lion, and energy densities of potential sea lion prey, off Chubut Province (northern Patagonia, Argentina). P: pelagic habitat; B: benthic habitat; $\mathrm{n}_{1}$ :sample size for isotope analysis; $\mathrm{n}_{2}$ : sample size for energy density; $(-)$ no data

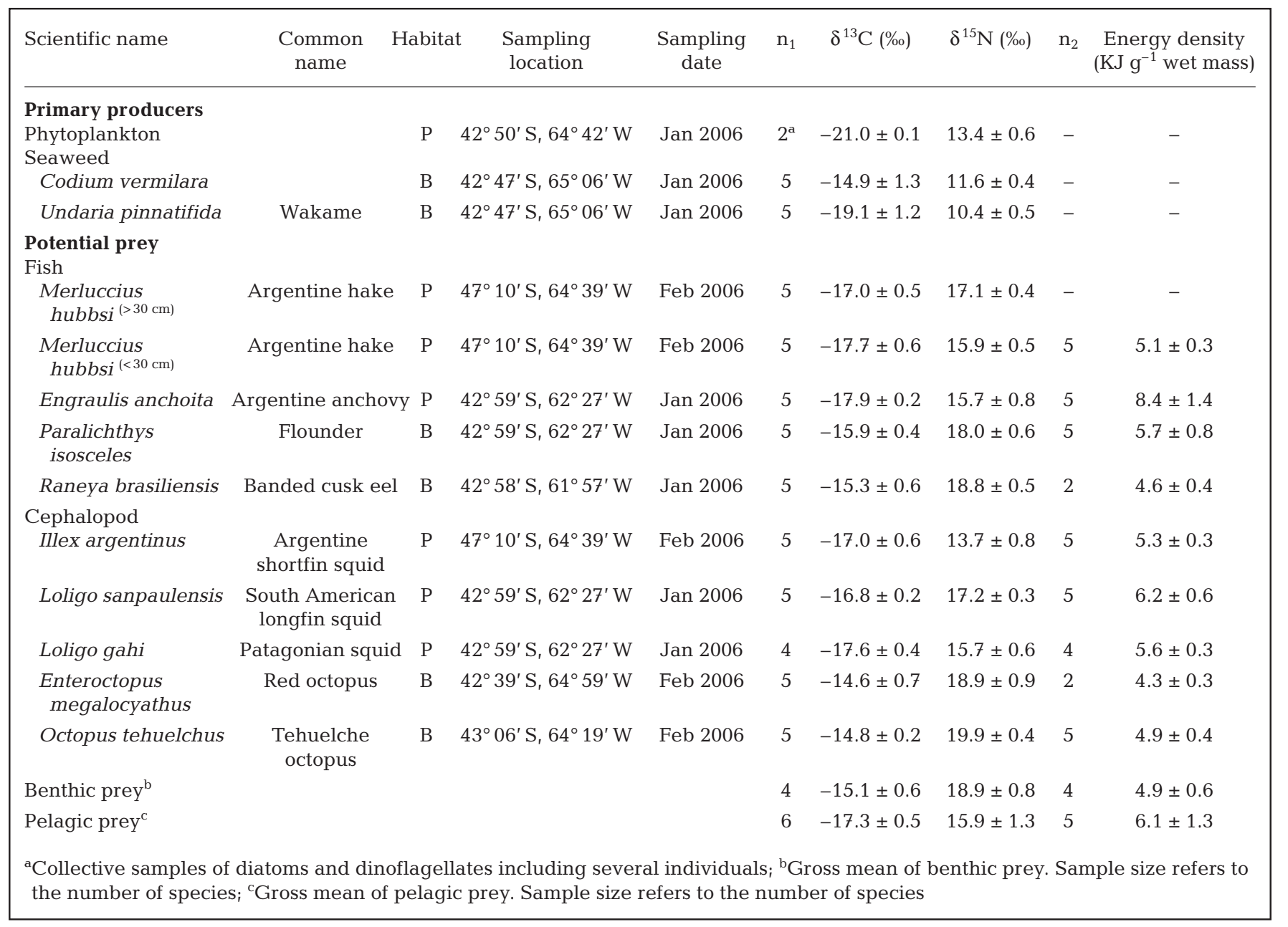

although the energy density also differed among species from the same habitat (Tables $2 \& 3$ ). The isotopic signal and energy density of the red octopus and hake, the 2 main prey species of South American sea lions (Koen Alonso et al. 2000), showed the same pattern, as the red octopus was more enriched in ${ }^{13} \mathrm{C}$ and ${ }^{15} \mathrm{~N}$ and had a lower energy density than hake (Fig. 3, Table 2).

Sex and period had statistically significant effects on the $\delta^{13} \mathrm{C}$ of the bone of the skulls collected in Chubut Province (Table 4). The absence of a significant interaction term in the 2-way ANOVA (Sex $\times$ Period) indicates that males and females have responded in the same way to the changes in northern Patagonia since the 1940s. Post hoc tests conducted independently for each sex (males ANOVA: $F_{3,36}=18.849, \mathrm{p}<0.001$; females ANOVA: $F_{3,31}=4.790, \mathrm{p}=0.007$ ) demonstrated that the $\delta^{13} \mathrm{C}$ of both males and females increased from the first to the second period and that differences did not exist between the first and the fourth period for either sex (Fig. 4A,B).

The linear regression analysis of the values for skulls from the CENPAT collection confirmed that bone $\delta^{13} \mathrm{C}$ has decreased steadily in both sexes since the 1970s, (Fig. 5) and that the magnitude of the decline was the same in both sexes, because although the regression equations were different, they resulted in 2 parallel lines (test of coincidence: $F_{2,56}=31.28, \mathrm{p}<0.001$; test of parallelism: $t=0.572$, df $=56, \mathrm{p}=0.550)$. Considering the above-reported differences in the $\delta^{13} \mathrm{C}$ of potential prey, both males and females are thought to have reduced the consumption of pelagic prey from the 1940 s to the 1970 s and to have increased it again since the 1970s.

Period was the only factor with a statistically significant effect on the $\delta^{15} \mathrm{~N}$ of the bone of the skulls collected in Chubut Province, as the sex and interaction terms of the 2-way ANOVA (Sex $\times$ Period) were not 
Table 3. Nested ANOVA to test for differences in the $\delta^{13} \mathrm{C}, \delta^{15} \mathrm{~N}$ and energy density of the considered prey species within habitat (benthic vs. pelagic)

\begin{tabular}{|c|c|c|c|c|c|c|}
\hline & SS & df & MS & $F$ & $\mathrm{p}$ & $\mathrm{r}^{2}$ \\
\hline \multicolumn{7}{|l|}{$\delta^{13} \mathrm{C}(\% \circ)$} \\
\hline Model & 66.950 & 9 & 7.439 & 30.903 & $<0.001$ & 0.877 \\
\hline Intersect & 12659.920 & 1 & 12659.920 & 52592.339 & $<0.001$ & \\
\hline Habitat & 56.610 & 1 & 56.610 & 235.170 & $<0.001$ & \\
\hline Species(Habitat) & 10.644 & 8 & 1.331 & 5.527 & $<0.001$ & \\
\hline Error & 9.388 & 39 & 0.241 & & & \\
\hline Total & 13321.060 & 49 & & & & \\
\hline \multicolumn{7}{|l|}{$\delta^{15} \mathrm{~N}(\%)$} \\
\hline Model & 155.593 & 9 & 17.288 & 51.296 & $<0.001$ & 0.922 \\
\hline Intersect & 14340.188 & 1 & 14340.188 & 42549.248 & $<0.001$ & \\
\hline Habitat & 107.413 & 1 & 107.413 & 318.709 & $<0.001$ & \\
\hline Species(Habitat) & 48.302 & 8 & 6.038 & 17.915 & $<0.001$ & \\
\hline Error & 13.144 & 39 & 0.337 & & & \\
\hline Total & 14510.510 & 49 & & & & \\
\hline \multicolumn{7}{|l|}{ Energy density } \\
\hline Model & 49.233 & 8 & 6.154 & 13.061 & $<0.001$ & 0.783 \\
\hline Intersect & 954.248 & 1 & 954.248 & 2025.230 & $<0.001$ & \\
\hline Habitat & 11.824 & 1 & 11.824 & 25.095 & $<0.001$ & \\
\hline Species(Habitat) & 38.781 & 7 & 5.540 & 11.758 & $<0.001$ & \\
\hline Error & 13.664 & 29 & 0.471 & & & \\
\hline Total & 1317.425 & 38 & & & & \\
\hline
\end{tabular}

Table 4. Otaria flavescens. Two-way ANOVA tests (Sex $\times$ Period) performed to compare the $\delta^{13} \mathrm{C}$ and the $\delta^{15} \mathrm{~N}$ of both sexes of South American sea lions in the 4 periods considered

\begin{tabular}{|c|c|c|c|c|c|c|}
\hline & SS & $\mathrm{df}$ & MS & $F$ & $\mathrm{p}$ & $\mathrm{r}^{2}$ \\
\hline \multicolumn{7}{|l|}{$\delta^{13} \mathrm{C}(\%)$} \\
\hline Model & 32.917 & 7 & 4.702 & 10.438 & $<0.001$ & 0.522 \\
\hline Intersect & 10359.815 & 1 & 10359.815 & 22994.355 & $<0.001$ & \\
\hline Period & 25.996 & 3 & 8.665 & 19.234 & $<0.001$ & \\
\hline Sex & 2.774 & 1 & 2.774 & 6.157 & 0.016 & \\
\hline Period $\times$ Sex & 2.227 & 3 & 0.742 & 1.648 & 0.187 & \\
\hline Error & 30.186 & 67 & 0.451 & & & \\
\hline Total & 10879.910 & 75 & & & & \\
\hline \multicolumn{7}{|l|}{$\delta^{15} \mathrm{~N}(\%)$} \\
\hline Model & 16.590 & 7 & 2.370 & 2.505 & 0.024 & 0.207 \\
\hline Intersect & 35852.152 & 1 & 35852.152 & 37887.323 & $<0.001$ & \\
\hline Period & 15.144 & 3 & 5.048 & 5.334 & 0.002 & \\
\hline Sex & 0.961 & 1 & 0.961 & 1.016 & 0.317 & \\
\hline Period $\times$ Sex & 2.450 & 3 & 0.817 & 0.863 & 0.465 & \\
\hline Error & 63.401 & 67 & 0.946 & & & \\
\hline Total & 37617.970 & 75 & & & & \\
\hline
\end{tabular}

statistically significant (Table 4). Post hoc tests conducted independently for each sex (males ANOVA: $F_{3,36}=1.685, \mathrm{p}=0.188$; females ANOVA: $F_{3,31}=7.360$, $\mathrm{p}<0.001)$ revealed that the female skulls from the first period were more enriched in ${ }^{15} \mathrm{~N}$ than those from the other periods and there was no difference in the $\delta^{15} \mathrm{~N}$ of male skulls in the 4 periods considered (Fig. 4C,D). Such a conclusion is reinforced by the absence of correlation between the stranding year and the $\delta^{15} \mathrm{~N}$ of female skulls from the CENPAT collection (Fig. 5). The same was true for the $\delta^{15} \mathrm{~N}$ of the males (Fig. 5). These results suggest that males also increased the consumption of those benthic prey enriched in ${ }^{15} \mathrm{~N}$, like octopuses, in parallel to the consumption of pelagic prey, thus stabilizing the $\delta^{15} \mathrm{~N}$ of skull bone. The same was true for the females, except in the 1940s.

The analysis of male skulls from the Acatushún Museum (Tierra del Fuego) revealed no change with time either in $\delta^{13} \mathrm{C}$ or in $\delta^{15} \mathrm{~N}$ values (Fig. 5). This result is unlikely to be an artefact caused by a small sample size or an uneven temporal distribution of samples, as indicated by the randomisation exercise carried out with the samples from Chubut Province. This exercise was conducted to test the influence of a sample size and a temporal distribution of samples like that of the Acatushún Museum collection on the capacity to detect the existence of a statistically significant negative correlation between stranding year and the $\delta^{13} \mathrm{C}$ of bone. The result of the exercise was that such a correlation was detected in $98 \%$ of the randomised populations, thus indicating a probability of not identifying a correlation when it exists of only $2 \%$, equivalent to a p-value of 0.02 .

\section{DISCUSSION}

The energy density of prey plays a central role in the foraging ecology of at least some otariids (Rosen \& Trites 2000, Staniland et al. 2007). The energy density of pelagic potential prey for sea lions Otaria flavescens off Chubut Province is much higher than that of the benthic potential prey (present study), so sea lions might be expected to show a preference for pelagic prey if energy density were the only criteria for prey selection. In such a scenario, the per capita consumption of pelagic prey would be expected to have increased from the 1940s to the 1970s, due to the resulting reduction in intraspecific competition caused by sealing and the concomitant reduction in the population of sea lions (Fig. 2b). Conversely, the per capita consumption of pelagic prey would be expected to have decreased since the 1970s, 

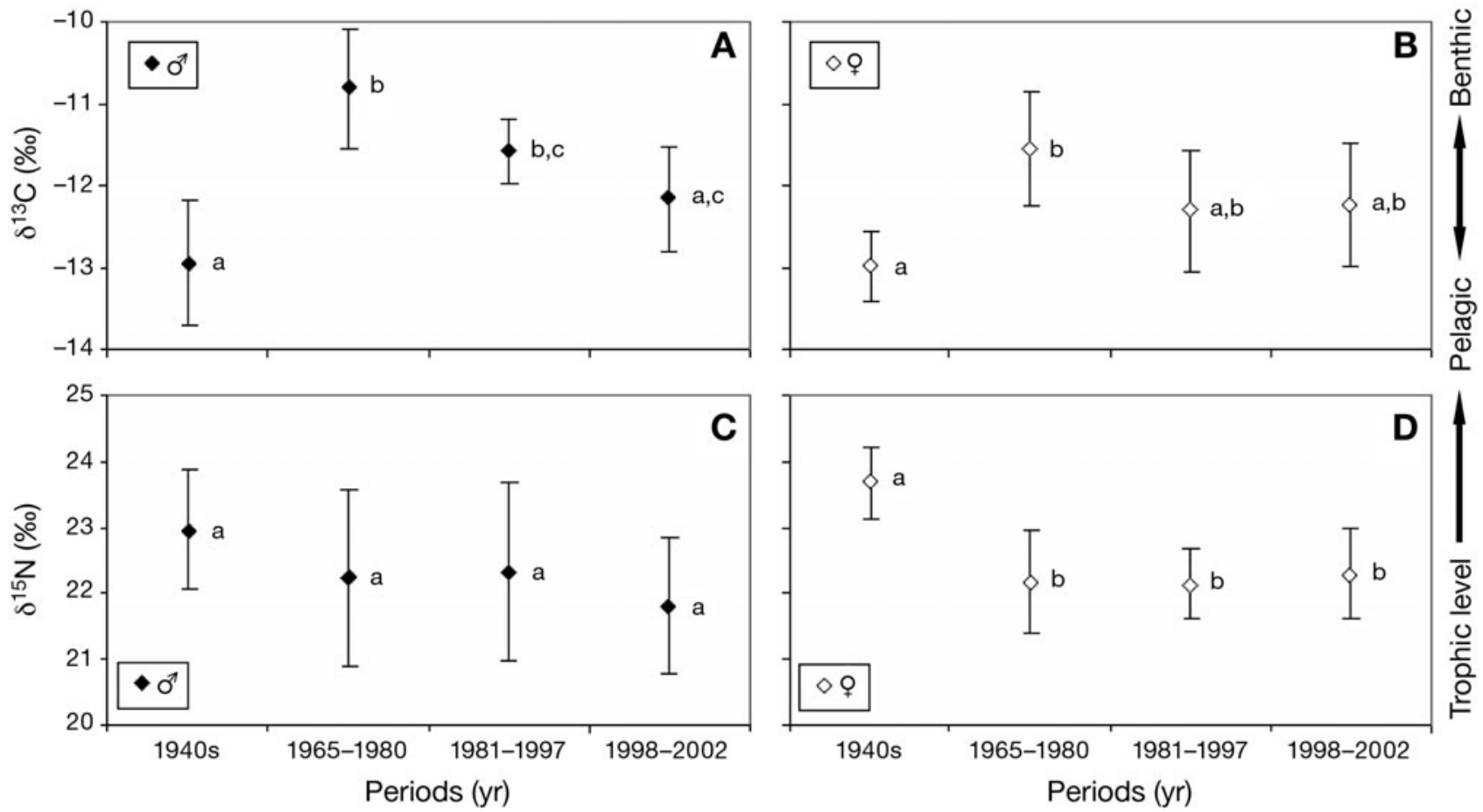

Fig. 4. Otaria flavescens. Mean $( \pm \mathrm{SD})$ values of $(\mathrm{A}, \mathrm{B}) \delta^{13} \mathrm{C}$ and $(\mathrm{C}, \mathrm{D}) \delta^{15} \mathrm{~N}$ for bone from the skulls of South American sea lions collected in Chubut Province (Penínusla Valés hunting site and CENPAT collection) in 4 contrasting periods. Periods with different lower-case letters differ in their mean values. Sample size: $\mathrm{n}=10$ for each sex and period, except females in the $1940 \mathrm{~s}(\mathrm{n}=5)$

due to the development of industrial fishing targeting pelagic species, the decline of the hake stock (Fig. 2a) and the partial recovery of the sea lion population (Fig. 2b).

The isotopic data presented here do not allow a precise reconstruction of the composition of diet of South American sea lions since the 1940 s, because prey-topredator fractionation factors have not been determined experimentally for this species. Furthermore, the fractionation factors determined experimentally for other pinniped species (Hobson et al. 1996, Kurle 2002) are for tissues other than bone, and, due to the high divergences observed among tissues, any diet reconstruction based on them will be meaningless. However, the isotopic data presented here are useful in detecting changes in the relative contribution of benthic and pelagic prey to the diet of South American sea lions.

If the relative contribution of Argentine hake and other pelagic prey to the diet of South American sea lions had decreased in response to the development of industrial fishing, the $\delta^{13} \mathrm{C}$ of skull bone would have had to increase. The changes in the $\delta^{13} \mathrm{C}$ of skull bone reported here follow exactly the opposite pattern (Fig. 2c), so the current diet should be viewed as the result of a shift from a benthic-based diet in the 1970s to a current diet based on a large fraction of pelagic prey, mainly Argentine hake. Furthermore, the similarity between the bone isotopic signals of the sea lions stranded in the 2000s and those collected from a hunting site in the 1940s indicate similar diets in both periods (Figs. 2 \& 4).

Increased per capita consumption of Argentine hake Merluccius hubbsi and other pelagic prey at a time when the hake population was decreasing is a paradoxical result, but it can be explained by 3 independent, non-excluding mechanisms: (1) increased availability of juvenile hake due to cannibalism release, (2) increased consumption of discarded hake by sea lions and (3) increased exploitation of pelagic feeding grounds due to increased intraspecific competition at benthic foraging grounds as the sea lion population grew.

Cannibalism is common in the Argentine hake (Angelescu \& Prenski 1987), so increased survival of young size classes might be expected if fishing reduced the number of older specimens (Laevastu \& Favorite 1988). This scenario is consistent with the length structure of the hake population in the 1990s, when individuals shorter than $30 \mathrm{~cm}$ dominated the population (Bezzi et al. 2004), but nothing is known about the length structure of the hake population in the 1970s.

On the other hand, the Argentine hake Merluccius hubbsi and Argentine red shrimp Pleoticus muelleri fisheries discarded annually about $170000 \mathrm{t}$ of undersized $(<30 \mathrm{~cm})$ Argentine hake in the late 1990s off northern Patagonia (Crespo et al. 1997, Cañete et al. 2000, Dato et al. 2003b, Aubone et al. 2004). This is 

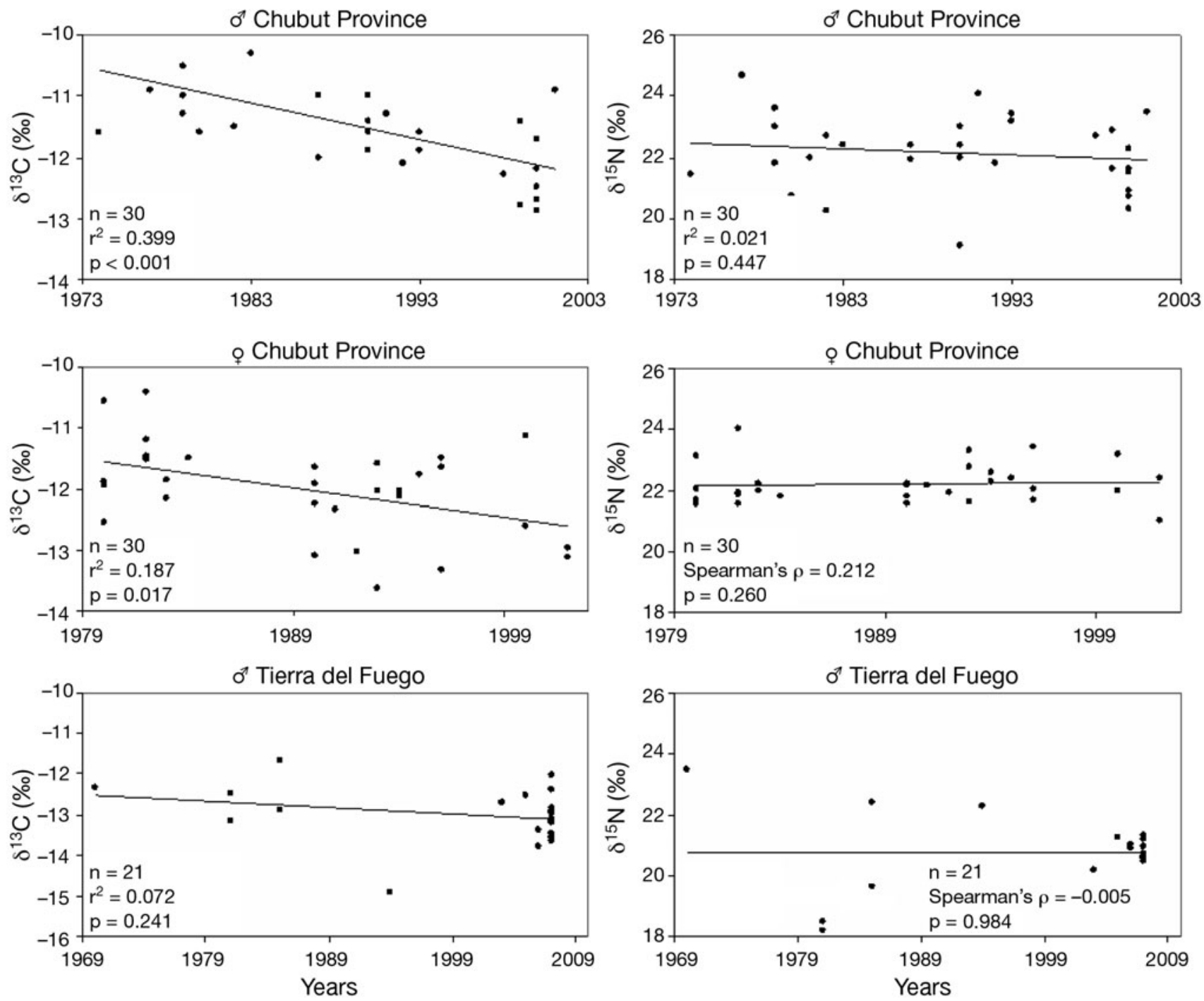

Fig. 5. Otaria flavescens. Linear regression and non-parametric correlation between the year of stranding and the isotopic signal $\left(\delta^{13} \mathrm{C}\right.$ and $\left.\delta^{15} \mathrm{~N}\right)$ of skull bone of adult male and female South American sea lions from the CENPAT collection (Chubut Province) and adult males from the Acatushún Museum (Tierra del Fuego)

precisely the preferred size of the Argentine hake consumed by South American sea lions (Crespo et al. 1997), and the total biomass of discarded Argentine hake is slightly larger than the biomass expected to be consumed annually by the population of South American sea lions in the same region (152565 t in agreement with Koen Alonso \& Yodzis 2005). Although South American sea lions were certainly unable to locate every discarded hake, discarding probably increased availability.

The hypothesis that South American sea lions have increased their consumption of hake off northern Patagonia because of increased intraspecific competition for benthic resources (Crespo \& Pedraza 1991) is supported by the opposing changes in isotopic signal and population experienced since the 1940s (Fig. 2b,c).
Further support comes from the higher nutritional value of pelagic prey (present study), which may compensate for longer foraging trips when exploiting offshore, pelagic feeding grounds (Staniland et al. 2007). A third line of evidence is the unexpected absence of differences between the isotopic values of males and females both in the 1940s and in the 2000s. South American sea lions are highly dimorphic, with males doubling females in weight (Cappozzo 2002). Dive time and dive depth in pinnipeds depend on oxygen stores and, hence, on body mass (Costa et al. 2004), which often result in males of highly dimorphic species diving deeper and/or longer than females (Le Boeuf et al. 1996, 2000). The data reported here were consistent with a more intense use of benthic resources by males in the 1970s and the 1990s, but not in the 1940s and the 
2000s, when the isotopic signal of both sexes was indistinguishable and consistent with a pelagic-based diet for both sexes.

Comparison with the feeding habits of South American sea lions in other regions reveals the relevance of industrial fishing in the above-reported changes. South American sea lions off central Chile, for instance, have also been reported to have shifted recently to a more pelagic diet (Hückstädt \& Antezana 2003, Hückstädt et al. 2007), due to the development of a purse-seine fishery targeting pelagic fish (Hückstädt \& Antezana 2003) and increased accessibility to pelagic prey. Conversely, the isotopic signals of male South American sea lions from Tierra del Fuego, where commercial fishing is scarce, have probably not changed in the past 3 decades (present study), although this should be considered a preliminary conclusion due to the small sample size and the uneven temporal distribution of samples. However, the apparent absence of changes reinforces the hypothesis that the increased consumption of Argentine hake off northern Patagonia is a local phenomenon caused paradoxically by the development of industrial fishing.

However, a number of confounding factors may interfere with the interpretation of the temporal change in the isotopic signal of the sea lion skull bone and have to be ruled out before concluding that sea lions have actually increased their per capita consumption of Argentine hake. The first of those factors is the invasion of Chubut Province by the $\delta^{13} \mathrm{C}$-depleted benthic macrophyte Undaria pinnatifida, first detected in Argentina in 1992 and currently one of the dominant species in the subtidal assemblage of benthic macrophytes off $\mathrm{Chu}$ but Province (Casas et al. 2004). The arrival of $U$. pinnatifida to the coast off northern Patagonia might have caused a drop in the $\delta^{13} \mathrm{C}$ of the whole food web and, hence, a decrease in the $\delta^{13} \mathrm{C}$ of the skulls of the local sea lions. However, U. pinnatifida was recorded for the first time off Chubut Province in 1992, well after the beginning of the decline of the $\delta^{13} \mathrm{C}$ in the skulls of South America sea lions.

The second possible confounding factor is a general change in surface ocean carbon reservoirs, due to the increasing concentrations of ${ }^{13} \mathrm{C}$-depleted atmospheric $\mathrm{CO}_{2}$ as a consequence of fossil fuel burning, a phenomenon invoked by Cullen et al. (2001) and Newsome et al. (2007) to explain the decline of the $\delta^{13} \mathrm{C}$ values of several species from the western Gulf of Alaska and eastern Bearing Sea throughout the second half of the 20th century (but see Schell 2000). In such a scenario, the $\delta^{13} \mathrm{C}$ of the sea lions from Tierra del Fuego was also expected to decrease, but it remained stable. The northern Patagonia dataset failed also to reveal a pattern of steady decline consistent with the Suess effect (Cullen et al. 2001), because the $\delta^{13} \mathrm{C}$ values of the bone from the skulls increased from the 1940s to the 1970 s and then declined.

Cyclical changes in the primary production of the southwestern Atlantic are a third possible confounding factor. Primary production in the southwestern Atlantic is influenced by El Niño Southern Oscillation (ENSO) and the periodic rotation of the subtropical anticyclone (Venegas et al. 1996, Fiedler 2002). A reduction in primary production is known to reduce the $\delta^{13} \mathrm{C}$ of primary producers and therefore the isotopic values of the entire food web (Bidigare et al. 1997), so the abovereported decline in the $\delta^{13} \mathrm{C}$ of sea lion skull bone might just reflect the periodicity of those climatic processes if samples were collected in periods of contrasting productivity. However, this is an unlikely explanation, as the ENSO and the displacement of the subtropical anticyclone have a cyclic frequency of 4 and $15 \mathrm{yr}$, respectively, and the skull dataset from northern Patagonia covers 30 yr with evenly spaced samples.

Conversely, the Pacific Decadal Oscillation (PDO) may have contributed to the observed variability, although the possible links between PDO and productivity in the southwestern Atlantic are obscure. The typical period of the PDO is over 20 to $30 \mathrm{yr}$, and the last warm phase lasted from 1976 to 2000 (Mantua \& Hare 2002), thus overlapping with the northern Patagonia dataset (1974 to 2002). Interestingly, the sea lions stranded dead in northern Patagonia earlier than 1982 may have experienced the effects of the last years of the 1947 to 1975 cold phase of the PDO and those stranded dead in 2001 and 2002 may have experienced the effects of a new cold phase just for a short period before death. The sea lions sloughed at the hunting site at Península Valdés in the 1940s may have also experienced the transition from a warm (1925 to 1946) to a cold (1947 to 1975) phase (Mantua et al. 1997) and, hence, might have experienced environmental conditions like those of the sea lions stranded dead in northern Patagonia in the late 1990s and early 2000s. Remarkably, the $\delta^{13} \mathrm{C}$ values of the sea lions collected in the 1940s and those stranded dead in the late 1990s and early 2000s are similar and differ from those of the sea lions stranded dead in the late 1970 s.

Furthermore, the dataset from northern Patagonia spans over a period of steady changes in a number of atmospheric parameters, such as the anomalies of the global air temperature, the atmospheric circulation index and the atmospheric $\mathrm{CO}_{2}$ measured at Mauna Loa (Chavez et al. 2003). Changes in these parameters are known to be related with multidecadal changes in ecosystem dynamics in the Pacific Ocean (Chavez et al. 2003), and the anomalies of the global air temperature and atmospheric circulation index in the 1940s were similar to those in the late 1990s. As a consequence, the changes in the isotopic signal reported 
here from northern Patagonia are consistent with a possible regimen shift in the southwestern Atlantic related to the regimen shift in the Pacific Ocean reported by Chavez et al. (2003), although the dataset from Tierra del Fuego revealed no major changes in the region. Nevertheless, the possible causal mechanism of such a hypothetic regime shift in the southwestern Atlantic is unknown, and no other evidence exists to our knowledge. As a consequence, increased consumption of pelagic prey, mostly hake, by South American sea lions off Chubut Province stands as the most likely hypothesis consistent with the patterns of isotopic change reported here, a result demonstrating the capacity of South American sea lions to recover their original role in the food web despite the profound changes in the ecosystem caused by human activity.

Acknowledgements. We thank the staff of the Marine Mammal Laboratory of the Centro Nacional Patagónico (CENPATCONICET), for overall assistance and logistic support during field work. The Ministry of Education and Science (MEC) of Spain supported M.D. through a PhD fellowship. The study was funded by the Fundación BBVA through the project 'Estudio de las amenazas para la conservación de mamíferos marinos de Patagonia' (BIOCON 04), Programa Nacional de Biodiversidad, Ciencias de la Tierra y Cambio Global of the MEC of Spain through the project 'CGL2005-00922/BOS', GEF/PNUD through the project 'Conservación de la Diversidad Biológica Marina y Prevención de la Contaminación en Patagonia' (ARG 02/018) and the Zoo d'Amneville, France.

\section{LITERATURE CITED}

Angelescu V, Fuster de Plaza ML (1965) Migraciones verticales rítmicas de la merluza del sector bonaerense (Merluciidae, Merluccius hubbsi) y su significado ecológico. An Acad Bras Cienc 37:194-214

Angelescu V, Prenski LB (1987) Ecología trófica de la merluza común del mar argentino (Merlucciidae, Merluccius hubbsi), Parte 2. Dinámica de la alimentación analizada sobre la base de las condiciones ambientales, la estructura y las evaluaciones de los efectivos en su área de distribución. Contrib INIDEP 561:1-205

Aubone A, Bezzi SI, Cañete G, Castrucci R and others (2004) Evaluación y sugerencias de manejo del recurso merluza (Merluccius hubbsi). La situación hasta 1999. In: Sánchez RP, Bezzi SI (eds) El mar Argentino y sus recursos pesqueros, Tomo 4. Los peces marinos de interés pesquero. Caracterización biológica y evaluación del estado de explotación. Publ Espec INIDEP, Mar del Plata, p 207-235

Bertolotti MI, Verazay GA, Akselman R (2001) El mar Argentino y sus Recursos Pesqueros. In: Boschi E (ed) Evolución de la flota pesquera argentina, artes de pesca y dispositivos selectivos, Vol 3. Publ Espec INIDEP, Mar del Plata

Bezzi SI, Renzi M, Irusta G, Santos B and others (2004) Caracterización biológica y pesquera de la merluza (Merluccius hubbsi). In: Sánchez RP, Bezzi SI (eds) El mar Argentino y sus recursos pesqueros, Tomo 4. Los peces marinos de interés pesquero. Caracterización biológica y evaluación del estado de explotación. Publ Espec INIDEP, Mar del Plata, p 157-205
Bidigare RR, Fluegge A, Freeman KH (1997) Consistent fractionation of ${ }^{13} \mathrm{C}$ in nature and in the laboratory: growth rate effects in some haptophyte algae. Global Biogeochem Cycles 11:279-292

Bligh EG, Dyer WJ (1959) A rapid method of total lipid extraction and purification. Can J Biochem Physiol 37:911-917

Bonner WN (1982) Seals and man: a study of interactions. Washington University Press, Seattle

Bunn SE, Loneragan NR, Kempster MA (1995) Effects of acid washing on stable isotope ratios of $\mathrm{C}$ and $\mathrm{N}$ in penaeid shrimp and seagrass: implications for food-web studies using multiple stable isotopes. Limnol Oceanogr 40: $622-625$

Cañete GR, Dato C, Villarino MF (2000) Caracterización del proceso de descarte de merluza (Merluccius hubbsi) en la flota de buques congeladores y factorías. Resultados preliminares a partir de los datos recolectados por observadores del INIDEP en seis mareas realizadas entre agosto y diciembre de 1995. INIDEP Inf Tec 32:1-18

Cappozzo HL (2002) South American sea lion (Otaria flavescens). In: Perrin WF, Würsing B, Thewissen JGM (eds) Encyclopedia of marine mammals. Academic Press, San Diego, CA, p 1143-1146

Carribero A, Pérez D, Yorio P (1995) Actualización del estado poblacional del pingüino patagónico Spheniscus magellanicus en Península Valdés, Chubut, Argentina. El Hornero 14:33-37

Casas G, Scrosati R, Piriz ML (2004) The invasive kelp Undaria pinnatifida (Phaeophyceae: Laminariales) reduces native seaweed diversity in Nuevo Gulf (Patagonia, Argentina). Biol Invasions 6:411-416

Chavez P, Ryan J, Lluch-Costa SE, Niquen M (2003) From anchovies to sardines and back: multidecadal change in the Pacific Ocean. Science 299:217-221

Clarke A, Holmes LJ, Gore DJ (1992) Proximate and elemental composition of gelatinous zooplankton from the Southern Ocean. J Exp Mar Biol Ecol 155:55-68

> Costa DP, Kuhna CE, Weisea MJ, Shaffer SA, Arnould JPY (2004) When does physiology limit the foraging behaviour of freely diving mammals? Int Congr Ser 1275: 359-366

Costa DP, Weise MJ, Arnould JPY (2006) Potential influences of whaling on the status and trends of pinniped populations. In: Estes JA, Demaster DP, Doak DF, Williams TM, Brownell RL (eds) Whales, whaling and ocean ecosystems. University of California Press, Berkeley, p 344-359

> Craig JF, Kenley MJ, Talling JF (1978) Comparative estimations of the energy content of fish tissue from bomb calorimetry, wet oxidation, and proximate analysis. Freshw Biol 8:585-590

Crespo EA (1988) Dinámica poblacional del lobo marino de un pelo Otaria flavescens (Shaw, 1800), en el norte del Litoral Patagonico. PhD dissertation, Universidad Nacional de Buenos Aires

Crespo EA, Pedraza SN (1991) Estado actual y tendencia de la población de lobos marinos de un pelo (Otaria flavescens) en el litoral norpatagónico. Ecol Austral 1:87-95

Crespo EA, Schiavini A, Perez Macri G, Reyes L, Dans S (1994) Estudio sobre la determinación de edades en mamíferos marinos del Atlántico Sudoccidental. In: Oporto JA (ed) Proc IV Reun Trab Esp Mam Acuat América del Sur Valdivia, Chile. Centro de Investigación y Manejo de Mamíferos Marinos, Valdivia, p 31-55

> Crespo EA, Pedraza SN, Dans SL, Koen Alonzo M and others (1997) Direct and indirect effects of the high seas fisheries on the marine mammal populations in the northern and central Patagonian coast. J Northwest Atl Fish Sci 22:189-207 
Cullen JT, Rosenthal Y, Falkowski PG (2001) The effect of anthropogenic $\mathrm{CO}_{2}$ on the carbon isotope composition of marine phytoplankton. Limnol Oceanogr 46:996-998

Dans SL, Koen Alonso M, Crespo EA, Pedraza SN, García NA (2003) Interactions between marine mammals and high seas fisheries in Patagonia: an integrated approach. In: Gales N, Hindell M, Kirkwood R (eds) Marine mammals: fisheries, tourism and management issues. CSIRO Publishing, Collingwood

Dans SL, Crespo EA, Pedraza SN, Koen Alonso M (2004) Recovery of the South American sea lion population (Otaria flavescens) in northern Patagonia. Can J Fish Aquat Sci 61:1681-1690

Dato CV, Villarino MF, Cañete GR (2003a) Dinámica de la flota comercial Argentina dirigida a la pesquería de merluza (Merluccius hubbsi) en el mar Argentino. Período 1990-1997. INIDEP Inf Tec 53:1-25

Dato CV, Villarino MF, Cañete GR (2003b) El descarte en la flota comercial argentina dirigida a la pesquería de merluza. Período 1990-1997. INIDEP Inf Tec 51:97-110

- DeNiro MJ, Epstein S (1977) Mechanism of carbon isotope fractionation associated with lipid synthesis. Science 197: 261-263

> DeNiro MJ, Epstein S (1978) Influence of diet on the distribution of carbon isotopes in animals. Geochim Cosmochim Acta 42:495-506

DeNiro MJ, Epstein S (1981) Influence of diet on the distribution of nitrogen isotopes in animals. Geochim Cosmochim Acta 45:341-351

Eder EB, Lewis MN (2005) Proximate composition and energetic value of demersal and pelagic prey species from the SW Atlantic Ocean. Mar Ecol Prog Ser 291:43-52

Emslie SD, Patterson WP (2007) Abrupt recent shift in $\delta^{13} \mathrm{C}$ and $\delta^{15} \mathrm{~N}$ values in Adélie penguin eggshell in Antarctica. Proc Natl Acad Sci USA 104:11666-11669

Fiedler PC (2002) Environmental change in the eastern tropical Pacific Ocean: a review of ENSO and decadal variability. Mar Ecol Prog Ser 244:265-283

Giangiobbe SM, Verazay GA, Ibáñez PM (1993) Análisis del comportamiento de la flota pesquera argentina sobre el recurso merluza durante el período 1985-1988. Frente Marítimo 14:23-32

Gnaiger E, Bitterlich G (1984) Proximate biochemical composition and caloric content calculated from elemental CHN analysis: a stoichiometric concept. Oecologia 62: 289-298

Godoy JC (1963) Fauna Silvestre. Serie: Evaluación de los Recursos Naturales de la Argentina. Consejo Federal de Inversiones, Buenos Aires

Grandi MF, Dans SL, Crespo EA (2008) Social composition and spatial distribution of colonies in an expanding population of South America sea lions. J Mammal 89:1218-1228

Hirons AC, Schell DM, Finney BP (2001) Temporal records of $\delta^{13} \mathrm{C}$ and $\delta^{15} \mathrm{~N}$ in North Pacific pinnipeds: inferences regarding environmental change and diet. Oecologia 129:591-601

> Hobson KA (1993) Trophic relationships among high Arctic seabirds: insights from tissue-dependent stable-isotope models. Mar Ecol Prog Ser 95:7-18

Hobson KA, Clark RG (1992) Assessing avian diets using stable isotopes. I. Turnover of ${ }^{13} \mathrm{C}$ in tissues. Condor 94:181-188

> Hobson KA, Schell DM, Renouf DY, Noseworthy E (1996) Stable carbon and nitrogen isotopic fractionation between diet and tissues of captive seals: implications for dietary reconstructions involving marine mammals. Can J Fish Aquat Sci 53:528-533

> Hodgson DA, Johnston NM (1997) Inferring seal populations from lake sediments. Nature 387:30-31
Hoffmann J, Nuñez M, Piccolo MC (1997) Características climáticas del océano Atlántico sudoccidental. In: Boschi E (ed) El mar Argentino y sus recursos pesqueros, Vol 1. Antecedentes históricos de las exploraciones en el mar y las características ambientales. Publ Espec INIDEP, Mar del Plata, p 163-193

> Hückstädt LA, Antezana T (2003) Behaviour of the southern sea lion (Otaria flavescens) and consumption of the catch during purse-seining for jack mackerel (Trachurus symmetricus) off central Chile. ICES J Mar Sci 60:1003-1011

> Hückstädt LA, Rojas CP, Antezana T (2007) Stable isotope analysis reveals pelagic foraging by the southern sea lion in central Chile. J Exp Mar Biol Ecol 347:123-133

Jackson JBC, Sala E (2001) Unnatural oceans. Sci Mar 65: $273-281$

> Koen Alonso M, Yodzis P (2005) Multispecies modelling of some components of the marine community of northern and central Patagonia, Argentina. Can J Fish Aquat Sci 62: 1490-1512

Koen Alonso M, Crespo EA, Pedraza SN, Garcia NA, Coscarella MA (2000) Food habits of the South American sea lion, Otaria flavescens, off Patagonia, Argentina. Fish Bull (Wash DC) 98:250-263

Koen Alonso M, Crespo EA, García NA, Pedraza SN, Mariotti PA, Mora NJ (2002) Fishery and ontogenetic driven changes in the diet of the spiny dogfish, Squalus acanthias, in Patagonian waters, Argentina. Environ Biol Fishes 63:193-202

Kurle CM (2002) Stable-isotope ratios of blood components from captive northern fur seals (Callorhinus ursinus) and their diet: applications for studying the foraging ecology of wild otariids. Can J Zool 80:902-909

Laevastu T, Favorite F (1988) Fishing and stock fluctuation. Fishing News Books, Farnham

Le Boeuf BJ, Morris PA, Blackwell SB, Crocker DE, Costa DP (1996) Diving behavior of juvenile northern elephant seals. Can J Zool 74:1632-1644

Le Boeuf BJ, Crocker DE, Costa DP, Blackwell SB, Webb PM, Houser DS (2000) Foraging ecology of northern elephant seals. Ecol Monogr 70:353-382

Lee-Thorp JA, Sealy JC, Van Der Merwe NJ (1989) Stable carbon isotope ratio difference between bone collagen and bone apatite, and their relationship to diet. J Archaeol Sci 16:585-599

Lloris D, Matallanas J, Oliver P (2003) Merluzas del Mundo (familia Merlucciidae). Catálogo comentado e ilustrado de las merluzas conocidas. FAO Catálogo de Especies para los Fines de la Pesca, No 2, FAO, Rome

> Lorrain A, Savoye N, Chauvaud L, Paulet Y, Naulet N (2003) Decarbonation and preservation method for the analysis of organic $\mathrm{C}$ and $\mathrm{N}$ contents and stable isotope ratios of low-carbonated suspended particulate material. Anal Chim Acta 491:125-133

Mantua NJ, Hare SR (2002) The Pacific decadal oscillation. J Oceanogr 58:35-44

- Mantua NJ, Hare SR, Zhang Y, Wallace JM, Francis RC (1997) A Pacific interdecadal climate oscillation with impacts on salmon production. Bull Am Meteorol Soc 78:1069-1079

Myers RA, Worm B (2003) Rapid worldwide depletion of predatory fish communities. Nature 423:280-283

National Research Council (2002) The decline of the Steller sea lion in Alaskan waters: untangling food webs and fishing nets. Committee on the Alaska Groundfish Fishery and Steller Sea Lions, National Academy Press, Washington, DC $>$ Newsome SD, Etnier MA, Aurioles-Gamboa D, Koch PL (2006) Using carbon and nitrogen isotope values to investigate maternal strategies in northeast Pacific otariids. Mar Mamm Sci 22:556-572 
Newsome SD, Etnier MA, Kurle CM, Waldbauer JR, Chamberlain CP, Koch PL (2007) Historic decline in primary productivity in western Gulf of Alaska and eastern Bering Sea: isotopic analysis of northern fur seal teeth. Mar Ecol Prog Ser 332:211-224

Ogawa N, Ogura N (1997) Dynamics of particulate organic matter in the Tamagawa Estuary and inner Tokyo Bay. Estuar Coast Shelf Sci 44:263-273

Pauly D, Christensen V, Dalsgaard J, Froese R, Torres FJR (1998) Fishing down marine food webs. Science 279: 860-863

Petraitis PS, Dudgeon SR (2004) Detection of alternative stable states in marine communities. J Exp Mar Biol Ecol 300: 343-371

Reyes L, Crespo EA, Szapkievich V (1999) Distribution and population size of the southern sea lion (Otaria flavescens) in central and southern Chubut, Patagonia, Argentina. Mar Mamm Sci 15:478-493

Rosen DAS, Trites AW (2000) Pollock and the decline of Steller sea lions: testing the junk-food hypothesis. Can J Zool 78:1243-1250

Schell DM (2000) Declining carrying capacity in the Bering Sea: isotopic evidence from whale baleen. Limnol Oceanogr 45:459-462

Schiavini ACM, Crespo EA, Szapkievich V (2004) Status of the population of South American sea lion (Otaria flavescens Shaw, 1800) in southern Argentina. Mamm Biol 69:108-118

Schoeninger MJ, DeNiro MJ (1984) Nitrogen and carbon isotopic composition of bone collagen from marine and terrestrial animals. Geochim Cosmochim Acta 48:625-639

Editorial responsibility: Yves Cherel, Villers-en-Bois, France
Sidwell VD, Foncannon PR, Moore NS, Bonnet JC (1974) Composition of the edible portion of raw (fresh or frozen) crustaceans, finfish, and mollusks. I. Protein, fat, moisture, ash, carbohydrate, energy value, and cholesterol. Mar Fish Rev 36:21-35

Springer AM, Estes JA, van Vliet GB, Williams TM and others (2003) Sequential megafaunal collapse in the North Pacific Ocean: an ongoing legacy of industrial whaling? Proc Natl Acad Sci USA 100:12223-12228

Staniland IJ, Boyd IL, Reid K (2007) An energy-distance trade-off in a central-place forager, the Antarctic fur sea (Arctocephalus gazelle). Mar Biol 152:233-241

> Thompson D, Strange I, Riddy M, Duck CD (2005) The size and status of the population of southern sea lions Otaria flavescens in the Falkland Islands. Biol Conserv 121: $357-367$

Tieszen LL, Boutton TW, Tesdahl KG, Slade NA (1983) Fractionation and turnover of stable carbon isotope in animal tissue: implications for $\delta^{13} \mathrm{C}$ analysis of diet. Oecologia 57: 32-37

Trites AW (1992) Northern fur seals: Why have they declined? Aquat Mamm 18:3-18

Trites AW, Donnelly LP (2003) The decline of Steller sea lion Eumetopias jubatus in Alaska: a review of the nutritional stress hypothesis. Mammal Rev 33:3-28

Venegas SA, Mysak LA, Straub DN (1996) Evidence for interannual and interdecadal climate variability in the South Atlantic. Geophys Res Lett 23:2673-2676

Zar JH (1984) Biostatistical analysis. Prentice-Hall, Englewood Cliffs, NJ

Submitted: November 18, 2008; Accepted: March 17, 2009 Proofs received from author(s): May 11, 2009 